\title{
Employment Status, Income Equality, and Poverty in Egypt
}

\author{
Hoda Abd El Hamid Ali \\ Assistant Professor of Economics/ the Economics Department \\ Faculty of Commerce and Business Administration / Helwan University, Cairo, Egypt \\ E-mail: hoda.abdelhamid@fue.edu.eg/hoda_hawary@yahoo.com
}

\section{Doi:10.5901/mjss.2013.v4n9p27}

\begin{abstract}
The present study examines trends in employment status in Egypt in an important era of democratic transition. It examines determinants of different labor force participation by gender. The empirical analysis is based on the World Values Survey of the fifth wave (2005-2008). A comparative descriptive approach is used to analyze the difference between males' and females' employment status. The study uses logistic regression analysis to examine the determinants of different labor force participation, and to examine the impact of different labor force practices and income equality on poverty. Empirical findings support a gender gap with respect to accessibility to full time paid work, only young females, regardless their computer skills, education attainment, marital status are more likely to be engaged in full time work, while those in middle age are more properly engaged in unpaid employment. The study also finds a gender gap in job search intensity. We also conclude that there is no linkage between employment status and poverty, however we find a positive and significant impact of females 'perception regarding the importance of having more equal distribution of income and their perception regarding the importance of poverty problem. These results show that women in Egypt are less engaged in decent jobs because they are less educated, having lower skills, more affected by income inequality and poverty. Social security should be reformed to cover all women, reforms are also needed for pensions, and unemployment insurance, to cover all retired, old age, care -giving, and unemployed individuals.
\end{abstract}

Keywords: Employment Status, Paid- Unpaid work, Formal and Informal work, Decent Work, Gender, Income Equality, Poverty, Egypt.

\section{Introduction}

The British newspaper "Financial Times" pointed out on the twenty seven of February 2013, that unemployment in Egypt is a ticking time bomb that threatened to burst, almost 162 thousand citizens lost their work in the past three months, rising unemployment to 3.5 million from a labor force of 27 million employees.

The newspaper mentioned that the unemployment rate rose to unprecedented levels registered $13 \%$ during the last three months of the last year, 2012, which might lead to a sever sluggish in the labor market in the country. This increase in unemployment rate is mainly due to the continued deterioration of the economic and security situation. According to official government data, unemployment rates before the revolution did not exceed $8.9 \%$, but after the revolution thousands of Egyptians lost their jobs especially those were working in the private sector and tourism companies.

The Egyptian economy is suffering from a lack of dynamism, with high unemployment; economic growth in 2012 did not exceed 1.9\%, while it was between 4 and $7 \%$ before the revolution. The country's labor force participation is low, and the responsiveness of employment to growth has been so weak in the last period. Egypt like other Arab countries needs a new development model that creates prosperity through equal opportunities and the government should bear the primary responsibility for helping the poor in their countries. The economic reforms in Egypt should balance economic growth with providing enough jobs and social services that allow men and women and their families to live in security and dignity (IMF, 2013:P.21).

The focus of this paper draws on the employment, income equality, and poverty linkages, without a better understanding of such relationship, development strategies aimed at poverty reduction, social justice may be incomplete, as employment is the principal channel through which economic growth reduces poverty. However access to employment is not sufficient to reduce poverty and inequality, the type and quality of work are also important. Many youth , housewives, or retired people are trapped in low- productivity, low or unpaid or other types of work that fall short of their aspirations and that often do not open opportunities to move to more permanent, higher- productivity and better-paid positions. 
Therefore, understanding the links between different types of employment status, poverty, and social justice are critical for formulating policy, as many reforms are needed regarding labor regulations to reduce disincentives for hiring and divert job seekers in to the informal sector, where workers do not enjoy the same level of protection as in the formal economy, revisiting public sector hiring practices, active labor market polices needed also to lower unemployment and to promote youth and female employment, and reforming the education system.

This Paper aims first, to analyze and test the factors that influence different practices and participation in the Egyptian labor force, more specifically what determines an individual's choice to work for paid employment (full or part time or self employment), or has no paid employment (students of all kinds and levels, household duties, retired or pensioned, unemployed, and others), and to test if the impact of these factors will differ according to gender. Second, linking these employment statuses with poverty and income equality, the paper examines the impact of an individual's choice of a specific employment status, and his/her perception regarding the importance of having more equal distribution of income on his/her perception regarding the importance of poverty, as the most serious problem in his or her country.

\subsection{Policy Importance:}

The results underline the importance of analyzing the factors that affect the different employment and unemployment (paid and unpaid employment) practices in the Egyptian labor force and analyzing the linkages between employment, poverty, and income equality, as nowadays the country is struggling and in its ongoing movements towards democracy. Reforming the labor market in Egypt is a major challenge for the country for poverty reduction, creating more social justice and a successful economic transition.

One of the most important studies on the determinants of employment status in Egypt was made by (Assad et, 2000), they examined the factors that sort individuals in to different employment states by gender by using multinomial logit models, It seeks to elucidate what factors affect who is economically active and who is not, who is working and who is unemployed, and among those working, who is a paid employee versus a casual wageworker versus a self-employed or family worker. The factors included in these models are region, Age, marital and headship status, educational attainment, household assets, presence of children and other social and community level variables. The study found that educated young women are more adversely affected than men by the transition to a private sector-led economy. Work, whether paid or unpaid, is the foundation of a nation's economy, while paid jobs are counted in the Gross National Product GNP; unpaid work is not counted as national income. Unpaid workers are not considered part of the labor force, and they are neglected by the government and left out of pension schemes, and other programs to support workers (George et al. 2009, P.10). Unpaid employment is considered to be one type of informal employment (Agel- Urdinola, D.F., and Tanabe,K. 2012,P.8), they show that unpaid work such as housing and child care, old age pensions, and disability are outside the formal sector and had limited access to government benefits.

Informality is defined as the collection of firms, workers, and activities that operate outside the legal and regulatory framework( De Soto, 1989), it is caused by a set of factors related to law and order, business regulatory freedom, average years of schooling, and socio-demographic factors, there are many studies tried to measure the extent of informality and its causes (see for example: Elbadawi,I and Loayza,N.2008), the study also found a positive relationship between informality and income inequality on poverty in Arab countries. However, there is insufficient empirical information on paid and unpaid work determinants, and implications on poverty especially for Egypt, for that reason the study uses micro data to measure the extent of paid and unpaid work, and to test its determinants and implications on poverty.

As the growth pattern of Egypt does not appear to be pro-poor, improvements in the rate of growth appear to have at best halted the spread of poverty and income inequality. Weak productivity performance and the low quality of employment help explain the poverty record and the non existence of social justice in the country. We expect to have positive and weak (insignificant) relationship between employment status and poverty that all individuals despite their employment status (paid or unpaid) will agree that the poverty problem is the most serious in their country, and we also expect to have a positive and strong relationship between their perceptions regarding income equality with their perceptions regarding the importance of poverty problem.

The paper proceeds as follows: section two provides data and methodology, section three deals with the results of estimation, and the last section gives conclusions and recommendations of the study. 


\section{Data and Methodology}

The study depends on data on 3050 individuals from Egypt from age 18 and over in 2008 data existed for paid employment only for full-time work (30 hours per week or more), and five status for non paid employment (retired, housewife, students, unemployed, and other-voluntary) obtained from the (2005-2008) wave of the World Values Survey (WVS), the study depends on this survey as it is a multipurpose and include a wide range of variables not only related to demographic, and labor related characteristics, but it includes many other variables related to the perceptions of individuals in many aspects in politics, economics, environment, and national identity

Table 1 summarizes work status in Egypt in 2008 depending on the WVS data; the percentage of paid employment is $42.3 \%$, while unpaid employment accounts for $57.7 \%$, most of this unpaid work is performed by women (39.2\%). This issue should be given be given a key priority by policy makers in reforming labor market.

Table 1: Employment status in Egypt in 2008

\begin{tabular}{|l|c|}
\hline Employment Status & Percent \\
\hline Full time & $42.3 \%$ \\
\hline Retired & $7.4 \%$ \\
\hline Housewife & $39.2 \%$ \\
\hline Students & $1.8 \%$ \\
\hline Unemployed & $5.4 \%$ \\
\hline Other & $3.9 \%$ \\
\hline Total & $100 \%$ \\
\hline
\end{tabular}

Source: WVS wave (2005-2008)

One stylized fact can be drawn from table 1 that unpaid work in Egypt is larger than the paid work, and it is not included in national income with a large portion of unpaid women. Such work should be included in the GNP of a nation, and it also constitutes another challenge for the government in reforming social security system. Formal sector employees continued to bear maternity benefit costs, which made hiring women less desirable, several studies on intra-household bargaining have pointed to the need for women to have access to social security and welfare benefits (Agarwal 1997, MacDonald 1998). The very absence of social services in care-giving may be a factor that relegates women to part-time, low-quality jobs (Ruwanpura 2009, P.9).

Table 2 shows gender inequality for employment status in Egypt based on data from World Value Survey (20052008), female contribution in full employment is only $12.2 \%$ compared to $71.3 \%$ for men, while women in unpaid work account for $89.7 \%$, compared to $28.7 \%$ for men. The largest share of the unpaid women work is for housewives $80.1 \%$, a lot of studies found that the share of women in unpaid work is much more than men (see for example Antonopoulos, R.2008).

Table 2: Employment Status by Gender

\begin{tabular}{|c|c|c|c|c|c|c|c|}
\hline \multirow{4}{*}{$\begin{array}{l}\text { Employment } \\
\text { Status }\end{array}$} & \multicolumn{7}{|c|}{ Sex } \\
\hline & \multirow{3}{*}{ Total } & \multicolumn{3}{|c|}{ Male } & \multicolumn{3}{|c|}{ Female } \\
\hline & & \multirow{2}{*}{ Total } & \multicolumn{2}{|c|}{ Sex } & \multirow{2}{*}{ Total } & \multicolumn{2}{|c|}{ Sex } \\
\hline & & & Male & Female & & Male & Female \\
\hline Full time & $42.3 \%$ & $71.3 \%$ & $71.3 \%$ & - & $12.2 \%$ & - & $12.2 \%$ \\
\hline Retired & $7.4 \%$ & $12.6 \%$ & $12.6 \%$ & - & $1.9 \%$ & - & $1.9 \%$ \\
\hline Housewife & $39.2 \%$ & - & - & - & $80.1 \%$ & - & $80.1 \%$ \\
\hline Students & $1.8 \%$ & $2.1 \%$ & $2.1 \%$ & - & $1.5 \%$ & - & $1.5 \%$ \\
\hline Unemployed & $5.4 \%$ & $8.8 \%$ & $8.8 \%$ & - & $2.0 \%$ & - & $2.0 \%$ \\
\hline Other & $3.9 \%$ & $5.3 \%$ & $5.3 \%$ & - & $2.4 \%$ & - & $2.4 \%$ \\
\hline Total & $\begin{array}{c}3051 \\
(100 \%)\end{array}$ & $\begin{array}{c}1557 \\
(100 \%)\end{array}$ & $\begin{array}{c}1557 \\
(100 \%)\end{array}$ & $\begin{array}{c}0 \\
(100 \%)\end{array}$ & $\begin{array}{c}1494 \\
(100 \%)\end{array}$ & $\begin{array}{c}0 \\
(100 \%)\end{array}$ & $\begin{array}{c}1494 \\
(100 \%)\end{array}$ \\
\hline
\end{tabular}

Source: WVS wave (2005-2008) 
Explanations for the existence of segregated labor markets are not new. Since the 1970s feminist and economists sought to explain the gendered nature of labor markets. Neo-classical economists' interpretation of segregated labor markets is based on the rationality of employers and workers, according to this theory women's participation in paid/unpaid work is determined by human capital level, women with low human capital and minimum level of skills and training may choose to be involved in low quality work with low wage or to engage in unpaid work as house and child care work. Other Institutional and Marxist economists added class, and/or ethnicity as important factors that explain labor market segmentation. Dual labor market theory indicated that segmentation of labor market is mainly affected by educational, skills, and productivity differences. Feminist theories emphasized the role played by culture, norms, and social practices in labor markets segmentation (Ruwanpura, 2009).

The study presents multivariate logistic regression models exploring the factors predicting paid employment (Full time), unpaid employment for (housewives not otherwise employed, retired employees, students, unemployed, and others). Second, as the central focus of this paper is also to evaluate the employment- income equality and poverty linkages in Egypt, the study provides another logistic regression model to assess the impact of different employment status, and perceptions regarding the importance of having income equality on poverty.

The following table provides a complete description of the variables included in the multivariate models.

Table 3: Description of variables included in the estimated models

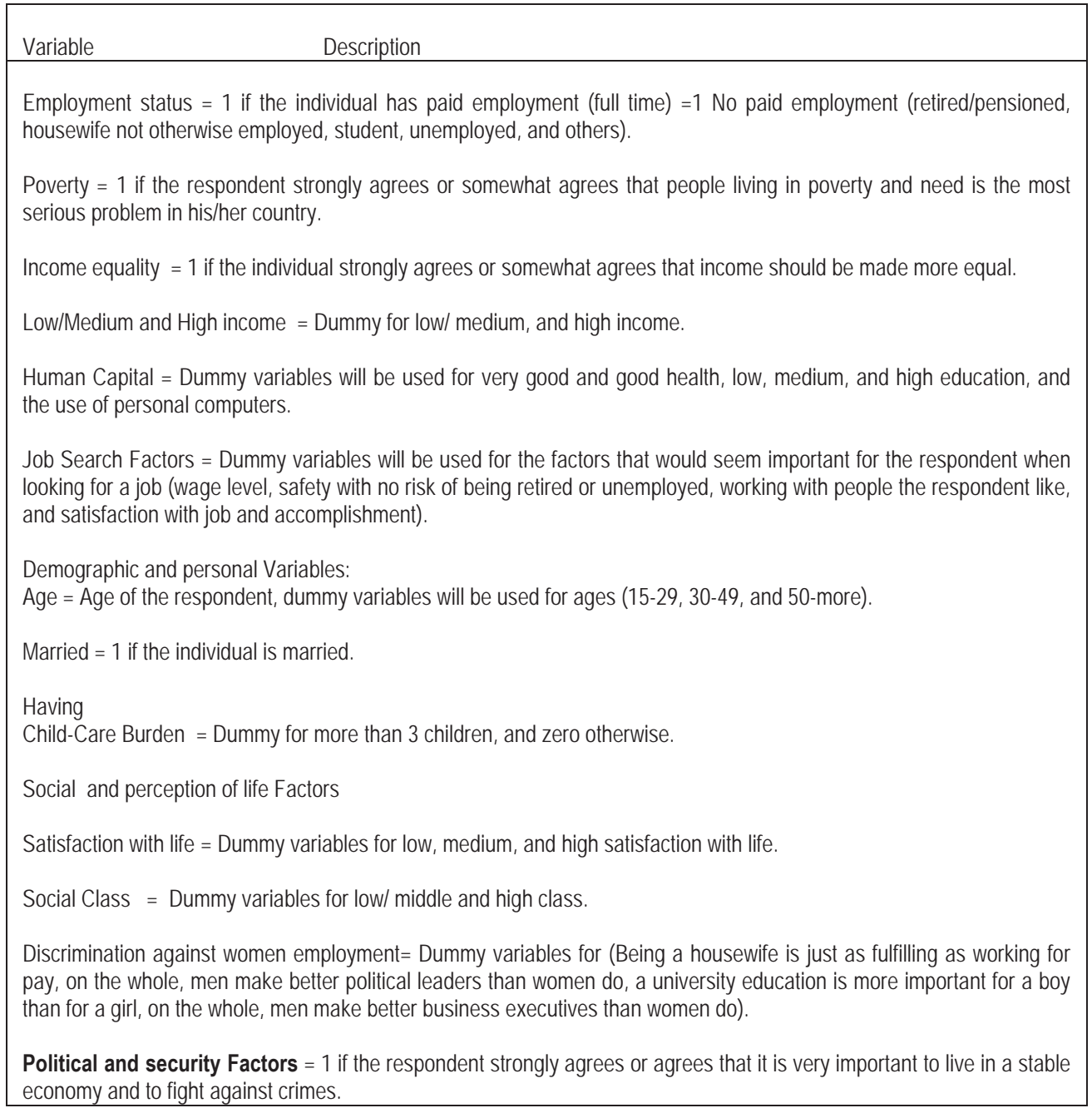
economy and to fight against crimes. 


\section{Results of the Estimated Models:}

Results are shown from tables (4-6), we omit males' student model from estimation for statistical problems and caution should be taken in interpreting results from unemployed, females' students, and retired models for low number of observations that may cause large coefficients.

Tables 4, and 5 show that young and middle aged men are less likely to be involved in full time work, while those who are in middle age are more properly retired or participate in other voluntary unpaid work. In contrast table 5 provides evidence that full time work is more likely to be among young females, while those who are in middle aged are more likely to be retired or involved in unpaid voluntary work. Results also indicate that early retirement and working in other unpaid employment are quite common for men and women surveyed in middle age as the number of hours spent on volunteer work increase with age (Johnson, et. 2008). Married males are less likely to be in full time work, while married females are more likely to be in full time work, the most relevant explanation to these findings that full time work is most properly available in public sector with low wage, but more flexible working conditions which makes it more attractive for women than men. Political and security factors have a weak impact on only participation in other (voluntary) work for males. Matching with the neo-classical economic theory, the study finds that education and human skills are important determinants of females' employment status. There is a positive and highly significant impact of education on female full time employment. The study also finds that young females irrespective of their educational attainment, and computer skills, are more likely to be involved in full time work. Other factors related to culture, norms and social practices such as discrimination against women factors also play an important role in determining females' participation in labor market for example, those who are strongly agree or agree that being a housewife as working for pay, and men make better executives than women have moderate and low positive significance impact on full time female employment. The most relevant explanation that perceptions regarding women's role in the society compared to males, are more likely to make them choose to engage in full time work, with flexible working conditions. On the other side middle aged females are not likely to have full time paid work, results of table 5 also indicates that the large share of females who are inactive due to household activities are mainly composed by a larger proportion of full-time housewives although they are unmarried, and have computer skills.

The results also show that there is a negative relation between education level and the probability of being housewives. Females who are belonging to upper middle, and lower middle classes are also less likely to be housewives. The results also suggest that women that strongly agree or agree that being a housewife like working for a pay, and those who also strongly agree or agree that men make better business executives than women are less likely to be housewives. Not surprising, youth female are less likely to be students as shown previously they are more likely to be engaged in full-time employment, females with secondary or technical education are less likely to be students as they are not enrolled in higher education, they do not complete their education to have full employment work; they are married, with no computer skills, with law and middle satisfaction with life, and they are not belonging to upper class or upper middle and lower middle class. The probability of being a student in females is also shaped by perceptions regarding the bias towards men's right in work and education, more specifically females who are strongly agree or agree that men make better business executives than women do are less likely to be students, but those who are strongly agree and agree that university education should not be for men only are more likely to be students. Unemployment in females is most likely to be shaped by age, education, and marital status factors. Those who are less educated, married, and not in young and middle age are more likely to be unemployed. Middle age females, who are married with either no, low, and moderate educations are strongly likely to be retired. The study also found that males who are strongly agree or agree that good income and safe job as the most important job search factors are more likely to be engaged in full time paid employment. The most relevant explanation to these results that job search intensity positively affects employment quality, because a more intense job search is likely to result in more job opportunities allowing the job seeker to choose the best alternative (Saks \& Ashforth, 2002; Van Hooft et al., 2005). In contrast young and middle aged females, having lower job search intensity than men, job search factors are only significant for other unpaid employment only (AbdelMowla, 2011). Other factors that have a similar impact on males' and females' employment status include:

The Perceived Health Status and Satisfaction with Life: The perceived health status as very good and good is only significant in determining males' employment status, those who perceive that they are in very good and good health are less engaged in full time paid work, we also noticed that those who are engaged in unpaid work are mostly among those who believe that they are in a very good and good health this findings may cause them to be either dissatisfied or with middle satisfaction with life. In general the study finds that those who are low satisfied with life are less likely to be engaged in full time work, on the other hand unpaid employment is more likely to be among those who are either 
dissatisfied with life or have middle satisfaction with life (see for example, Johnson, 2008).

Social Class: results indicate that in general those who are belonging to upper class or upper middle and middle class are less likely to be involved in unpaid work.

Income Level: the study finds that in general low or middle income levels are less likely to be participated in unpaid work. The results shown in table 6 provide strong evidence to support that there is no/ or weak linkage between employment status and poverty in Egypt, for the entire sample surveyed we couldn't find any significance impact of the type of employment status on poverty, most signs were negative ,only we found unemployed males are less agreeing that the poverty problem is the most important problem, on the other hand we found a moderate and significant positive impact of perceptions regarding the importance of the equality of distribution of income, and the perceptions regarding the importance of the poverty problem among females.

Table 4: Multinomial logistic regression of type of employment status for males

\begin{tabular}{|c|c|c|c|c|}
\hline Variables & Full Time & Unemployed & Retired & Others \\
\hline Constant & 0.158 & $38.065^{\star \star \star}$ & 1.519 & 2.588 \\
\hline Age $15-29$ & $-2.103^{\star \star \star}$ & -0.779 & 0.000 & 0.200 \\
\hline Age $30-49$ & $-1.934^{\star \star *}$ & $-1.328^{\star \star}$ & $3.545^{\star \star *}$ & $1.732^{\star \star}$ \\
\hline Age $>50$ & 0.000 & 0.000 & 0.000 & 0.000 \\
\hline Married & $-1.505^{\star \star}$ & 0.431 & 0.638 & $1.366^{*}$ \\
\hline Children $>3$ & -0.109 & 0.572 & 0.101 & -0.512 \\
\hline Very good and good health & $-1.023^{\star \star \star}$ & 0.431 & $0.697^{\star *}$ & $1.905^{\star \star \star}$ \\
\hline No Formal Education & 0.152 & -0.782 & $0.869 *$ & $-2.657^{*}$ \\
\hline Basic Education & -0.107 & -0.527 & 0.258 & -1.229 \\
\hline Secondary and Technical Education & 0.247 & -0.827 & -0.140 & -0.918 \\
\hline Higher Education & 0.000 & 0.000 & 0.000 & 0.000 \\
\hline Never and do not know what computers are & 0.281 & -0.156 & -0.233 & -0.227 \\
\hline Low satisfaction with life & -0.193 & 0.537 & -0.284 & $1.018^{*}$ \\
\hline Middle satisfaction with life & -0.393 & $0.975^{\star}$ & 0.005 & -0.008 \\
\hline High satisfaction with life & 0.000 & 0.000 & 0.000 & 0.000 \\
\hline Upper Class & 1.080 & 0.000 & $-2.278^{\star}$ & 0.000 \\
\hline Upper and lower middle class & 0.003 & -0.385 & $-0.458^{*}$ & 0.104 \\
\hline Working and lower class & 0.000 & 0.000 & 0.000 & 0.000 \\
\hline Good Income & $0.786^{*}$ & -0.537 & -0.732 & -0.878 \\
\hline Safe job & $1.05^{\star \star}$ & -0.301 & $-1.252^{\star \star}$ & -0.727 \\
\hline Working with people you like & 0.524 & 0.322 & -0.867 & -0.144 \\
\hline A feeling of accomplishment & 0.000 & 0.000 & 0.000 & 0.000 \\
\hline Being a housewife as working for pay & 0.101 & -1.244 & 0.164 & 0.761 \\
\hline Men make better political leaders than women & 0.130 & 0.000 & 0.613 & -0.960 \\
\hline University education is more important for boys & 0.187 & -0.005 & -0.198 & -0.266 \\
\hline Men make better business executives & -0.360 & 0.538 & 0.407 & -0.706 \\
\hline Stable economy & 0.001 & -1.215 & 0.471 & $1.360^{* *}$ \\
\hline Fight against crimes & 0.003 & -0.921 & -0.549 & $1.317^{\star}$ \\
\hline Low income level & 0.572 & $-16.308^{\star \star \star}$ & -0.861 & 1.186 \\
\hline Middle income level & 0.432 & 0.000 & $-1.169^{\star}$ & $1.756^{\star}$ \\
\hline High income level & 0.000 & 0.000 & 0.000 & 0.000 \\
\hline No of Observations & 671 & 44 & 135 & 47 \\
\hline Nagelkerke $\mathbf{R}^{2}$ & 0.323 & 0.162 & 0.425 & 0.410 \\
\hline
\end{tabular}

${ }^{*},{ }^{* \star},{ }^{* \star *}$ denote significance at $10 \%, 5 \%$,and1\% respectively.

Table 5: Multinomial logistic regression of type of employment status for Females 


\begin{tabular}{|c|c|c|c|c|c|c|}
\hline Variable & $\begin{array}{l}\text { Full } \\
\text { Time }\end{array}$ & Housewives & Student & Unemployed & Retired & Others \\
\hline Constant & $-0.107^{\star}$ & $3.001^{\star * *}$ & 43.484 & $4.640^{\star \star}$ & -0.365 & $20.423^{\star \star \star}$ \\
\hline Age 15-29 & $1.136^{\star \star \star}$ & $-1.340^{\star \star \star}$ & -19.975 & $-2.651^{\star \star}$ & 20.263 & $3.058^{\star \star \star}$ \\
\hline Age $30-49$ & $-0.666^{\star \star}$ & -0.210 & -0.251 & $-2.165^{\star \star}$ & $2.491^{\star \star \star}$ & $2.807^{\star \star \star}$ \\
\hline Age $>50$ & 0.000 & 0.000 & 0.000 & 0.000 & 0.000 & 0.000 \\
\hline Married & $0.830^{\star \star \star}$ & $-1.703^{\star \star \star}$ & $6.737^{\star \star \star}$ & $2.276^{\star \star \star}$ & $1.433^{\star \star}$ & $1.745^{\star \star \star}$ \\
\hline Children $>3$ & 0.009 & -0.202 & 9.243 & 0.255 & 0.283 & 0.599 \\
\hline Very good and good health & -0.232 & 0.163 & 0.000 & 0.577 & 0.345 & -0.006 \\
\hline No Formal Education & 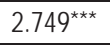 & $-2.606^{\star \star \star}$ & 9.448 & $2.506^{\star \star}$ & $3.321^{\star \star \star}$ & $1.745^{\star \star \star}$ \\
\hline Basic Education & $2.749 * \star \star$ & $-2.514^{\star \star \star}$ & 13.465 & $1.392^{\star}$ & $2.818^{\star \star \star}$ & 0.572 \\
\hline Secondary and Technical Education & $1.417^{\star \star \star}$ & $-1.196 * \star \star$ & $-5.370^{\star \star}$ & 0.722 & $1.196^{*}$ & -0.006 \\
\hline Higher Education & 0.000 & 0.000 & 0.000 & 0.000 & 0.000 & 0.000 \\
\hline $\begin{array}{l}\text { Never and do not know what } \\
\text { computers are }\end{array}$ & $0.671^{\star \star}$ & $-0.823^{\star * *}$ & $4.012^{\star * *}$ & -0.211 & -0.654 & $-2.712^{\star}$ \\
\hline Low satisfaction with life & $-0.472^{\star}$ & 0.001 & $4.683^{*}$ & -0.901 & -0.107 & $2.471^{\star \star}$ \\
\hline Middle satisfaction with life & 0.005 & -0.008 & $2.205^{\star}$ & -0.444 & 0.002 & 0.153 \\
\hline High satisfaction with life & 0.000 & 0.000 & 0.000 & 0.000 & 0.000 & 0.000 \\
\hline Upper Class & 0.004 & 0.676 & $-9.361^{\star \star}$ & 0.000 & 0.000 & 13.439 \\
\hline Upper and lower middle class & $0.396^{*}$ & $-0.302^{*}$ & $-1.938^{\star}$ & 0.331 & 0.595 & -0.424 \\
\hline Working and lower class & -0.191 & -0.455 & 0.000 & 0.000 & 0.000 & 0.000 \\
\hline Good Income & -0.269 & -0.268 & 0.357 & 0.151 & 0.577 & 1.479 \\
\hline Safe job & -0.216 & -0.205 & 1.483 & -0.208 & -0.206 & $1.595^{\star}$ \\
\hline Working with people you like & -0.191 & -0.455 & 2.570 & 0.885 & -0.323 & 1.675 \\
\hline A feeling of accomplishment & 0.000 & 0.000 & 0.000 & 0.000 & 0.000 & 0.000 \\
\hline Being a housewife as working for pay & $0.604^{\star \star}$ & $-0.568^{\star \star}$ & 1.189 & -0.511 & 0.432 & 1.081 \\
\hline $\begin{array}{l}\text { Men make better political leaders } \\
\text { than women }\end{array}$ & -0.184 & 0.214 & $-2.117^{\star}$ & 0.001 & 0.616 & -0.545 \\
\hline $\begin{array}{l}\text { University education is more } \\
\text { important for boys }\end{array}$ & 0.003 & 0.214 & $3.671^{\star *}$ & -0.175 & -0.195 & $-1.239 * *$ \\
\hline Men make better business executives & $0.366^{*}$ & $-0.515^{\star \star}$ & $2.636^{\star *}$ & 0.001 & 0.490 & 0.314 \\
\hline Stable economy & 0.007 & -0.008 & -0.912 & 0.002 & 0.696 & -0.302 \\
\hline Fight against crimes & 0.008 & -0.206 & -1.765 & -0.718 & 0.172 & 17.256 \\
\hline Low income level & -0.145 & 0.622 & -3.856 & -0.564 & -1.063 & $-18.326^{\star \star \star}$ \\
\hline Middle income level & -0.117 & 0.550 & -3.203 & -0.291 & -1.707 & -17.509 \\
\hline High income level & 0.000 & 0.000 & 0.000 & 0.000 & 0.000 & 0.000 \\
\hline No of Observations & 224 & 1493 & 26 & 24 & 33 & 24 \\
\hline Nagelkerke $\mathbf{R}^{2}$ & 0.273 & 0.323 & 0.796 & 0.235 & 0.403 & 0.432 \\
\hline
\end{tabular}

${ }^{*},{ }^{\star \star},{ }^{* \star \star}$ denote significance at $10 \%, 5 \%$,and1\% respectively.

Table 6: Multinomial logistic regression of the impact of employment status and income equality on poverty for Men (Model 1), and females (Model 2)

\begin{tabular}{|l|c|c|}
\hline Variable & Model 1 & Model 2 \\
\hline Constant & 0.788 & 0.119 \\
\hline Full time & -0.601 & 0.000 \\
\hline Housewife & 0.000 & 0.121 \\
\hline Student & 0.000 & -0.006 \\
\hline
\end{tabular}




\begin{tabular}{|c|c|c|}
\hline Unemployed & $-1.245^{\star}$ & 0.000 \\
\hline Others & 0.000 & 0.000 \\
\hline Retired & -0.260 & 0.555 \\
\hline Age $15-29$ & 0.182 & -0.109 \\
\hline Age $30-49$ & 0.171 & 0.176 \\
\hline Age $>50$ & 0.000 & 0.000 \\
\hline Married & 0.910 & -0.007 \\
\hline Children $>3$ & 0.158 & -0.139 \\
\hline Very good and good health & 0.000 & -0.174 \\
\hline No Formal Education & -0.470 & 0.199 \\
\hline Basic Education & -0.470 & 0.121 \\
\hline Secondary and Technical Education & -0.104 & $0.431^{*}$ \\
\hline Higher Education & 0.000 & 0.000 \\
\hline Never and do not know what computers are & 0.133 & $-0.566^{\star *}$ \\
\hline Low satisfaction with life & $-0.691^{*}$ & $-0.498^{\star *}$ \\
\hline Middle satisfaction with life & -0.316 & $-0.535^{\star \star \star}$ \\
\hline High satisfaction with life & 0.000 & 0.000 \\
\hline Upper Class & 0.004 & $1.124^{\star}$ \\
\hline Upper and lower middle class & 0.137 & $0.259 *$ \\
\hline Working and lower class & 0.000 & 0.000 \\
\hline Good Income & $-0.718^{*}$ & -0.235 \\
\hline Safe job & -0.384 & $-0.512^{*}$ \\
\hline Working with people you like & -0.429 & -0.178 \\
\hline A feeling of accomplishment & 0.000 & 0.000 \\
\hline Being a housewife as working for pay & $-0.710^{*}$ & -0.003 \\
\hline Men make better political leaders than women & $-0.710^{*}$ & -0.232 \\
\hline University education is more important for boys & $-0.756^{*}$ & $0.273^{*}$ \\
\hline Men make better business executives & 0.251 & 0.482 \\
\hline Stable economy & -0.105 & $-0.373^{\star}$ \\
\hline Fight against crimes & -0.202 & -0.316 \\
\hline Low income level & $-0.807^{\star}$ & -0.128 \\
\hline Middle income level & $-1.033^{*}$ & -0.285 \\
\hline High income level & 0.000 & 0.000 \\
\hline Income should be made more equal & -0.005 & $0.428^{\star \star}$ \\
\hline No of Observations & 696 & 1472 \\
\hline Nagelkerke $\mathbf{R}^{2}$ & 0.099 & 0.086 \\
\hline
\end{tabular}

We also note from table 6 that, there is a significant relationship between moderate education and perceptions regarding the importance of the poverty problem among females. Discrimination against women variables have a significant negative impact on male's perceptions regarding the poverty problem, unlike females, most of these variables were insignificant and have a positive impact on poverty.

This gives indication that men are perceived that they have more rights than women in having better education and better work opportunities in their country and such perception has a negative impact on their perception regarding the importance of poverty problem. Other factors such as social class, computer skills, job search factors, satisfaction with life, political factors are also more important in explaining poverty among females, as most signs were negative and significant in model 2.

Our analysis has shown that females have more strong perception regarding the importance of the poverty 
problem men. Supporting the women, who are often poor, with specialized programs and other sorts of assistance seems highly justified.

\section{Conclusion}

This paper assesses the main micro- determinants of employment status in Egypt, and the joint impact of employment status and income equality on poverty by gender applied on a sample of 3050 individuals obtained from the (2005-2008) wave of the World Values Survey (WVS), the study concludes that there is a discrimination against women's role in the economy that make them less accessible to better education, health, and technical skills, and in returns to better work.

Women also are more affected by the inequality in distribution of income which makes them also more affected by the poverty problem in Egypt. Supporting the poor especially women, who are often poor, less accessible to better employment with specialized programs and other sorts of assistance seems highly justified. Social security should be reformed to cover all women, reforms are also needed for pensions, and unemployment insurance which was almost non-existent before 2010 , to cover all retired, old age, care -giving, and unemployed individuals.

The study also finds that employment status has weak and insignificant impact on poverty; such findings are resulted from the weak relationship between employment and growth. What is needed above all is an employment policy that puts the emphasis on strengthening the growth-employment linkages through promoting highly quality jobs and the notion of decent jobs in particular for the poor. The study also concludes that there is a positive and strong relationship between females' perceptions regarding the importance of having more equal distribution of income and their perceptions regarding the importance of the poverty problem in the Egyptian economy.

\section{References}

Abdel-Mowla,S.(2011). Trends and Determinants of Job Search Intensity of Unemployed Females: Empirical Evidence from Egypt. Mediterranean Journal of Social Sciences,2(3),98-110.

Agarwal, B.(1997). Bargaining' and Gender Relations: Within and Beyond the Household. Feminist Economics 3(1),1-51.

Agel- Urdinola, D.F., and Tanabe,K.( 2012).Micro-determinants of informal employment in the Middle East and North African region( discussion paper 1201).Social Protection and Labor: The World Bank.

Antonopoulos,A.(2008). The unpaid care work-paid work connection (Working paper 541). The Levy Economics Institute: International Labor Organization.

Assaad, R., Fatma,E.H., \& Akhter, U. A.(2000). The determinants of employment status in Egypt (discussion paper).Food Consumption and Nutrition Division: International Food Policy Research Institute, Washington, D.C, USA.

De Soto, H.(1989). The other path: the invisible revolution in the third world.

Elbadawi,I. \& Loayza, N.(2008). Informality, employment and economic development in the Arab world. Journal of Development and Economic Polices, 10(2), 25-75.

George,B., Natasha C. , Ashutosh,T.\& Phaeba ,A.(2009). Women's economic contribution through their unpaid work: the case of india. Evangelical Social Action Forum \& Health Bridge.

International Monetary Fund (March 2013), Finance and Development, available at http://www.imf.org/external/pubs /ft/fandd/2013/03/pd//fd0313.pdf.

Johnson,K.M.,Catsouphes,M.P.,Besen,E.,Smyer,M.\&Matz-Costa,C.(2008).Quality of employment and life satisfaction: a relationship that matters for older workers(Issue Brief 13).The Center on Aging \&Work: Boston College.

MacDonald, M. (1998). Gender and Social Security Policy: Pitfalls and Possibilities. Feminist Economics, 4(1).

New York: HarperCollins.

Ruwanpura, K.N.(2004). Quality of women's employment: A focus on the South (discussion paper 151). Decent work research program: International Institute for Labor Studies.

Saks, A. M., \& Ashforth, B. E. (2002). Is job search related to employment quality? It all depends on fit. Journal of Applied Psychology, 87, 646-54.

Van Hooft, E. A. J., Born, M. Ph., Taris, T. W., \& Filer, H. (2005). Predictors and outcomes of job search behavior: The moderating effects of gender and family situation. Journal of Vocational Behavior, 67 (2), 133-52.

World Values Survey. Available at http://www.worldvaluessurvey.org/. 